\title{
Porous anodic film formation on an Al-3.5 wt \% Cu alloy
}

\author{
M.A. Paez", P. Skeldon**, G.E. Thompson**, M. Saez*, \\ O. Bustos ${ }^{* * *}$ and A. Monsalve $e^{* * *}$
}

Abstract

Keywords Aluminium. Anodic films. Aluminium alloys.

The morphological development of porous anodic films in the initial stages is examined during anodising an $\mathrm{Al}-3.5 \mathrm{wt} \% \mathrm{Cu}$ alloy in phosphoric acid. Using transmission electron microscopy a sequence of ultramicrotomed anodic sections reveals the dynamic evolution of numerous features in the thickening film in the initial stages of anodising. The morphological changes in the anodic oxide in the initial stages of its formation appears related to the formation of bubbles during film growth. From Rutherford backscattering spectroscopy (RBS) analysis of the film, the formation of the bubbles is associated with the enrichment of copper in the alloy due to growth of the anodic oxide. On the other hand, during constant current anodising of $\mathrm{Al}-\mathrm{Cu}$ in phosphoric acid, the current efficiency is considerably less than that for anodising superpure aluminium under similar conditions. From the contrasting results between the charge consumed calculated from RBS and the real charge consumed during anodising, oxygen gas bubbles generation and copper oxidation seem to be of less importance on the low efficiency for film formation. It is apparent that the main cause of losing efficiency for film growth on $\mathrm{Al}-\mathrm{Cu}$ is associated with generation of oxygen at residual second phase, with the development of stresses in the film and, the consequence of these effects on film cracking during film growth.

\section{Formación de películas anódicas porosas en Al-3,5 \% p/p Cu}

Resumen

En este trabajo se examinó el desarrollo morfológico de películas anódicas porosas en los estados iniciales de la anodización de una aleación de aluminio Al-3,5\% p/p Cu. La observación de una secuencia de secciones ultramicrotomadas del metal y su película anódica, por microscopía electrónica de transmisión, revela la evolución dinámica de numerosos detalles morfológicos durante los inicios del crecimiento de la película anódica. Los cambios morfológicos en el óxido anódico, en los inicios de su formación, aparecen relacionados a la formación de burbujas durante el crecimiento de éste. A través de análisis por espectroscopía de reflexión Rutherford (RBS), la formación de burbujas, posiblemente de oxígeno, se asocia con el enriquecimiento de cobre en la aleación debido al crecimiento de la película anódica. Por otra parte, las cálculos de eficiencia anódica para la anodización de la aleación de aluminio a corriente constante, indican que ésta es bastante más baja que aquella determinada para la anodización de aluminio de alta pureza bajo condiciones similares. Sin embargo, la baja eficiencia anódica para la anodización de la aleación contrasta con los datos de carga consumida calculada desde los datos de RBS y la carga real consumida durante el anodizado. Así, la generación de burbujas de oxígeno y la oxidación de cobre parecen tener poca importancia en la baja eficiencia anódica durante la anodización de la aleación. Aparentemente, la baja eficiencia anódica está más relacionada con la generación de oxígeno en segundas fases residuales y con el desarrollo de tensiones en la película anódica durante su crecimiento. Esto último, con la consecuencia esperada de procesos de ruptura y reparación local de la película durante su crecimiento.

Palabras clave Aluminio. Anodizado. Películas anódicas.

(*) Universidad de Santiago de Chile, Facultad de Química y Biología, Departamento de Química de los Materiales.

(**) Corrosion and Protection Centre, University of Manchester, Institute of Science and Technology, Manchester, M60 1QD, U.K.

$\left.{ }^{(* * *}\right)$ Universidad de Santiago de Chile, Facultad de Ingeniería, Departamento de Metalurgia, Av. Libertador B O’Higgins 3363, Casilla 40, Correo 33, Santiago, Chile. 


\section{INTRODUCTION}

Anodic film on aluminium have widespread applications in areas ranging from architecture and aerospace ${ }^{[1]}$. Consiquently, the growth of barrier and porous film on highly pure aluminium has received extensive study, with factors controlling morphology, composition and structure examined $^{[2 \text { and } 3]}$. With regard to the commonly used alloys, effects at the matrix and fine and coarse second phase material have been probed. Generally, the behaviour of alloying elements depend on the Gibbs free energy of oxide formation per equivalent relative to alumina ${ }^{[4]}$. Thus, alloying element with $\Delta \mathrm{G}^{\circ} / \mathrm{n}$ values more negative than alumina co-oxidise with alumina; element with less negative values enrich to a critical level at the alloy/film interface. Thereafter, the alloy element may co-oxidise with alumina, i.e. $\mathrm{Ta}$, or oxidise and develop oxygen gas filled voids in the alumina film (i.e.Cu) or may be associated with gas generation alone (i.e. $\mathrm{Au}$ ).

In the case of aluminium alloys containing copper, porous anodic films are utilised for surface hardening and, as adherents for joining applications. Anodic film growth proceeds at relatively low current efficiency compared with the anodic oxidation of aluminium. A recent study has confirmed the low efficieny and the prior enrichment of copper below the alumina film, before its oxidation and associated oxygen gas generation ${ }^{[5]}$. However, film formation was undertaken in sulphuric acid, generating fine featured porous anodic alumina films, where discrimination of the various features is difficult. Consequently, here porous anodic film formation has been undertaken in phosphoric acid to relatively high voltages, allowing observation of the alloy/film interface, the attached alumina film and its developing porous morphology.

\section{EXPERIMENTAL PROCEDURE}

An Al-1.5 at \% Cu binary alloy, prepared from superpure aluminium and high purity copper, was provided as $1 \mathrm{~mm}$ thick sheet; specimens, of dimensions $40 \times 10 \mathrm{~mm}$, were cut from the sheet. In order to minimize any contributions from relatively coarse second phase material, developed during casting and fabrication, the specimens were solution heat treated at $530^{\circ} \mathrm{C}$ for $2 \mathrm{~h}$, followed by rapid quenching into water at room temperature.
Specimens were electropolished individually in a perchloric acid/ethanol mixture at $20 \mathrm{~V}$ for 5 min at temperatures below $10{ }^{\circ} \mathrm{C}$. After electropolishing, the specimens were rinsed thoroughly in distilled water, immersed in $50 \%$ nitric acid for $30 \mathrm{~s}$, rinsed in distilled water and finally dried in a cold air stream. Such treatments removed relocated copper and the low volume fraction of second phase material present at the alloy surface.

Anodizing was undertaken at a constant current density of $5 \mathrm{~mA} / \mathrm{cm}^{2}$ in $0.4 \mathrm{M} \mathrm{H}_{3} \mathrm{PO}_{4}$ at $20^{\circ} \mathrm{C}$ up to different voltages; the voltage/time behaviour was monitored during anodizing.

Ultramicrotomed sections of the alloy substrate and its attached anodic films were prepared in the usual manner on an LKB III Ultramicrotome 8800; the final sections, with nominal thickness set at $10 \mathrm{~nm}$, were supported on titanium grids. Observations of the electron transparent films and sections were undertaken in a Jeol 2000 FXII transmission electron microscope.

The compositions of the anodised specimens were determined by RBS using a $2.0 \mathrm{MeV}$ beam of alpha particles provided by the $2.5 \mathrm{MeV}$ Van de Graaff accelerator of the University de Paris. The oxygen contents of films were measured by Nuclear reaction analysis (NRA) using the ${ }^{16} \mathrm{O}(\mathrm{d}, \mathrm{p} .)^{17} \mathrm{O}$ reaction with a deuteron energy of $830 \mathrm{KeV}$.

\section{RESULTS}

The voltage-time response for anodizing the Al1.5 at \% $\mathrm{Cu}$ alloy under the selected conditions (Fig. 1) reveals an initial voltage surge of about $2 \mathrm{~V}$ due to the presence of the residual film formed in electropolishing. In the initial stages of anodizing the voltage response shows different rate of voltage rise. The voltage first rises linearly with time at a rate of $34 \mathrm{~V} \mathrm{~min}^{-1}$ up to $12 \mathrm{~V}$, then continues to rise at $57 \mathrm{~V} \mathrm{~min}^{-1}$ up to $43 \mathrm{~V}$. After this voltage, the voltage continues to rise at $36 \mathrm{~V} \mathrm{~min}^{-1}$, but at a progressively reduced rate to a maximum voltage of about $100 \mathrm{~V}$.

The voltage-time response for the alloy is different to that reported for anodizing of high purity aluminium under the selected conditions ${ }^{[3]}$ For superpure aluminium the voltage rises linearly with time at a rate of $78.8 \mathrm{~V} \mathrm{~min}^{-1}$ to about $120 \mathrm{~V}$ and then, to progressively reduced rate until a maximum voltage of about $150 \mathrm{~V}$ is reached. After reaching the maximum, the voltage decreases 


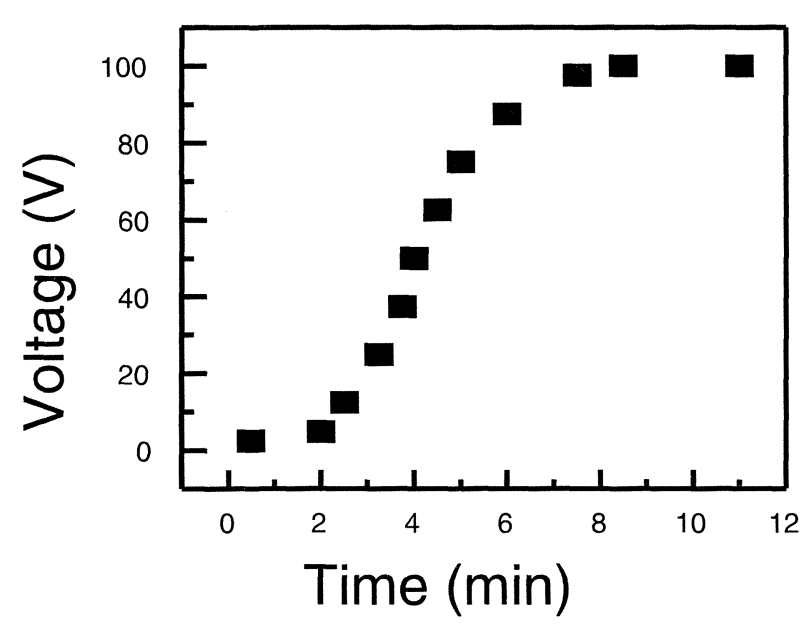

Figure 1. Voltage-time response for anodizing Al-1.5 at \% $\mathrm{Cu}$ at $5 \mathrm{~mA} \mathrm{~cm}{ }^{-2}$ in $0.4 \mathrm{M} \mathrm{H}_{3} \mathrm{PO}_{4}$.

Figura 1. Respuesta voltaje-tiempo para el anodizado de Al- $1,5 \% \mathrm{Cu}$ a $5 \mathrm{~mA} \mathrm{~cm}^{-2}$ en $\mathrm{H}_{3} \mathrm{PO}_{4} 0,4 \mathrm{M}$.

gradually with time, achieving a steady-state voltage of about $120 \mathrm{~V}$.

\subsection{Rutherford backscattering spectroscopy}

Simulated and experimental RBS spectra of specimens anodized to $100 \mathrm{~V}$ at $5 \mathrm{~mA} \mathrm{~cm}^{-2}$ were obtained; examples of typical spectra can be found elsewhere ${ }^{[8 \text { and } 9]}$. The spectra revealed the usual yields from an anodized aluminium alloy substrate, including yields from oxygen, copper and aluminium nuclei in the film and copper and aluminium nuclei in the alloy substrate. A particular feature of interest in the experimental spectrum was an increased yield from copper nuclei at the alloyoxide interface. The yields from phosphorous in the film and, from aluminium and copper in the film and in the enriched layer are given in table I.

Table I. Composition of anodic films formed in $0.4 \mathrm{M}$ $\mathrm{H}_{3} \mathrm{PO}_{4}$ at $20^{\circ} \mathrm{C}$ at $5 \mathrm{~mA} \mathrm{~cm}^{-2}$ to $100 \mathrm{~V}$ from RBS and NRA analyses

Tabla I. Composición de películas anódicas formadas a 20 ${ }^{\circ} \mathrm{C}$ en $\mathrm{H}_{3} \mathrm{PO}_{4} \mathrm{O}, 4 \mathrm{M}$ a $5 \mathrm{~mA} \mathrm{~cm} \mathrm{~cm}^{-2}$, hasta $100 \mathrm{~V}$. Los datos de composición fueron obtenidos por análisis RBS y NRA

\begin{tabular}{lc}
\hline \multicolumn{1}{c}{ Voltage } & $100 \mathrm{~V}$ \\
\hline Al atoms $/ \mathrm{cm}^{2}$ in alumina & $3.90 \times 10^{17}$ \\
O atoms $/ \mathrm{cm}^{2}$ forming alumina & $5.62 \times 10^{17}$ \\
O in the film (NRA) & $6.61 \times 10^{17}$ \\
$\mathrm{P}$ in the film & $5.93 \times 10^{16}$ \\
$\mathrm{Cu}$ atoms $/ \mathrm{cm}^{2}$ in the film & $5.93 \times 10^{15}$ \\
$\mathrm{Cu}$ atoms $/ \mathrm{cm}^{2}$ (enriched layer) & $3.93 \times 10^{15}$ \\
\hline
\end{tabular}

The amounts of oxygen in the films, determined by NRA, are also given in the table I. These quantities, which were measured at the same areas as the RBS data include both oxygen combined with aluminium and copper species in the film, ie as units of $\mathrm{Al}_{2} \mathrm{O}_{3}$ and $\mathrm{CuO}$, and oxygen present as oxygen atoms or molecules produced by oxidation of $\mathrm{O}^{2-}$ ions of the film material. There may also be minor contributions from any hydrated material at the surface of the film. In the present considerations, the oxygen associated with units of $\mathrm{CuO}$ can be neglected, relative to that associated with units of $\mathrm{Al}_{2} \mathrm{O}_{3}$, since the concentrations of copper ions in the films are about two orders of magnitude lower than those of $\mathrm{Al}^{3+}$ ions. In addition, from RBS the outer region of the film appear contaminated by phosphate species, which are possibly present as $\mathrm{PO}_{4}^{-3}$ units in the film. From phosphorous content in the film formed to $100 \mathrm{~V}$, given in table I, an additional incorporation of oxygen of about $9.09 \times 10^{16}$ atoms $\mathrm{cm}^{-2}$ is calculated. This oxygen content value plus that calculated for alumina formation fit well with the total amount of oxygen in the film.

From the aluminium yield, the charge involved in alumina formation is estimated, to be $0.19 \mathrm{C}$. From the ratio of the charge passed for alumina formation to the total charge passed during anodizing to $100 \mathrm{~V}, 0.88 \mathrm{C}$, estimation of the efficiency of film formation is possible. The efficiency for anodizing at $5 \mathrm{~mA} \mathrm{~cm} \mathrm{~cm}^{-2}$ up to $100 \mathrm{~V}$ is $22 \%$, which is considerably lower than that reported for film growth on superpure aluminium in $0.4 \mathrm{M}$ phosphoric acid, where oxide formation in the initial stages of anodizing occurs at $53.5 \%$. Thus, despite a significant loss of $\mathrm{Al}^{+3}$ ions, which is expected for film formation on aluminium in acid electrolytes ${ }^{[3]}$, there are additional contributions to the low efficiency for film formation. The main possible reason for the low efficiency for film formation may be associated with oxygen evolution proceeding above copper clusters in the metal film interface during film growth ${ }^{[9}$ and 10]. This observation is consistent with later TEM examination, where the presence of oxygen bubbles in the film are really evident. A further cause of loss of efficieny for film formation may be associated with ejection of copper ions to solution. Although for barrier oxide formation losses in efficiency of $<1 \%$ are reported, this may be enhanced during anodizing the Al-Cu alloy in acid electrolytes ${ }^{[5]}$. Further, in the very initial stages of anodizing, secondary electrochemical reactions, such as oxygen evolution, 
is possible to occur above second phase regions, which are unavoidable present in Al-Cu alloy of relatively high copper content. In this respect, it may be noted that the initial slopes of the voltagetime response are reduced compared with that for anodising high purity aluminium under similar condition, indicative of loss of efficiency. In previous work of the authors, such a reduction in slopes during anodizing $\mathrm{Al}-\mathrm{Cu}$ in acid electrolytes ${ }^{[5]}$ has been associated with oxygen evolution proceeding above second phase and impurity regions. Further, as a result of a non-uniform film growth and the expected tensile stresses in the film, film cracking is possible. Considering this, an additional cause of the loss of efficiency with respect to film growth on superpure aluminium may be related to cracking of the film in the initial stages of anodizing and generation of oxygen at residual second phase material.

In summary, the findings of the RBS and NRA analyses indicate that efficiency for film formation on the $\mathrm{Al}-\mathrm{Cu}$ alloy is considerably less than that for anodising aluminium of high purity. Significant loss of oxygen, and possible side reactions associated with residual second phase, appear to be prevalent during anodizing the $\mathrm{Al}-\mathrm{Cu}$ alloy.

\subsection{TEM Examination}

Transmission electron micrographs of ultramicrotomed sections of the aluminium substrate and the attached films are shown in figure 2 . At $20 \mathrm{~V}$, the alloy/film interface reveals a ridged appearance (Fig. 2a).

Above the ridged metal surface, a barrier film of average thickness, about $22 \mathrm{~nm}$, is observed. Local features in the anodic section exhibits local thickening of the oxide. Further, above corroded second phase materials, the film appear discontinuous, suggesting a non uniform film growth in the initial stages of anodising.

Additionally and importantly, for the film formed to $20 \mathrm{~V}$, the alloy-film interface reveals occasional local regions at the top of alloys ridges where cracking/healing events appear to have taken place (labelled by arrow). At $50 \mathrm{~V}$, a ridged or scalloped appearance is still observed at the alloy-oxide interface (Fig. 2b). However, local thickening of the oxide and light regions associated with oxygen gas bubbles in the film are clearly observed. The bubbles appear separated in the film and distributed throughout the anodic film

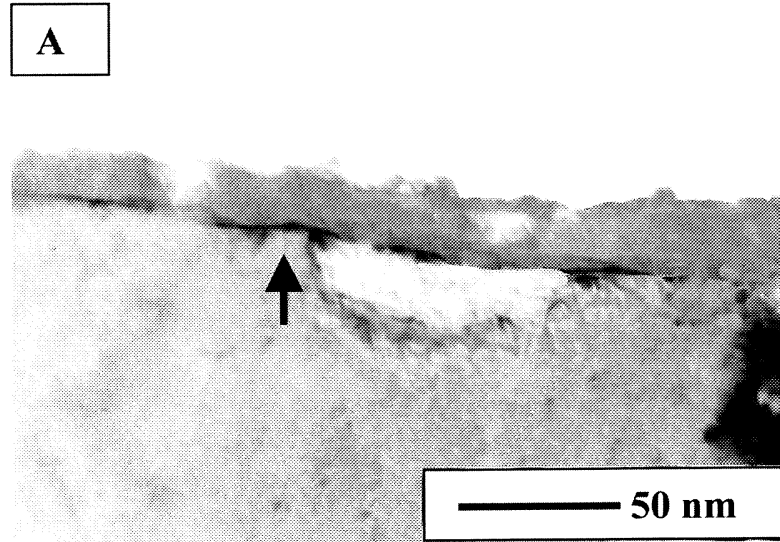

\section{B}

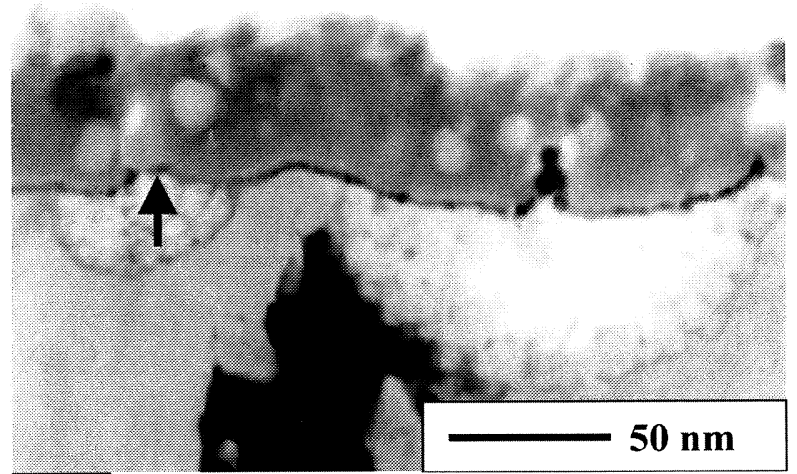

\section{C}

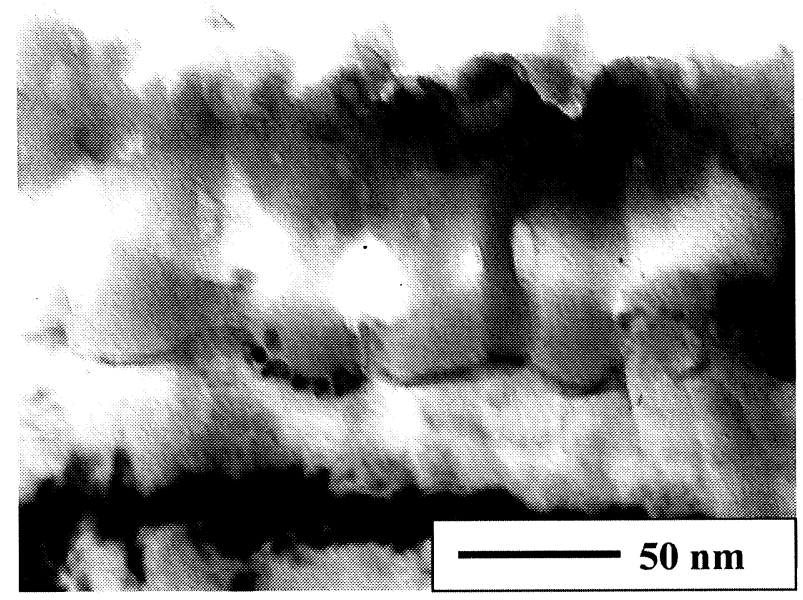

Figure 2. Transmission electron micrographs of ultramicrotomed sections of the $\mathrm{Al}-1.5$ at $\% \mathrm{Cu}$ and the anodic films formed at $5 \mathrm{~mA} \mathrm{~cm}{ }^{-2}$ in $0.4 \mathrm{M} \mathrm{H}_{3} \mathrm{PO}_{4}$ at $20^{\circ} \mathrm{C}$ to different voltages. A) $20 \mathrm{~V}$; B) $50 \mathrm{~V}$; C) $100 \mathrm{~V}$.

Figura 2. Micrografías obtenidas por microscopía electrónica de transmisión de secciones ultramicrotomadas de la aleación Al-1,5\% Cu y su película anódica formada a $5 \mathrm{~mA} \mathrm{~cm}^{-2}$ en $\mathrm{H}_{3} \mathrm{PO}_{4}$ a $20{ }^{\circ} \mathrm{C}$ hasta diferentes voltajes. A) $20 \mathrm{~V}$; B) $50 \mathrm{~V}$; C) $100 \mathrm{~V}$. 
thickness. A particular feature of interest here is the location of fine oxygen gas bubbles in the film material next to the alloy-film interface. Because of the alloy ridges and bubbles in the film, the film thickness is relatively non uniform along the length of the section., with a thickness variation of up to about $\pm 5 \%$ of the average film thickness, $50 \mathrm{~nm}$. As observed in the film formed to $20 \mathrm{~V}$, the alloy substrate in figure $2 \mathrm{~b}$ also reveals occasional local regions associated with cracking/healing events during film growth (labelled by arrow). With further film growth to $100 \mathrm{~V}$, the film thickens to about $111 \mathrm{~nm}$. Due to the increase in height above alloy ridges, which is not clearly observed in the micrograph, because the film appears bent on the top of the anodic section, the film between metal ridges exhibits increased curvature. From figure $2 c$ the onset of major pore growth is not evident. However, flaw regions appear spread wide in the middle of the film band, suggesting further flaw development and bubbles nucleation ${ }^{[6]}$ with increasing the anodising voltage.

A further and common feature of the anodic sections in figure 2 is the presence of a copper enriched layer, which is revealed directly as a dark band, about $2 \mathrm{~nm}$ thick, immediately beneath the anodic film at the alloy-film interface The average composition of the copper enriched layer determined from RBS is about $\mathrm{Al}-32,4$ at \% Cu.

\section{DISCUSSION}

\subsection{Morphology of anodic films}

An important revelation of this work is the presence of flaws associated with bubbles in anodic films formed in $\mathrm{Al}-\mathrm{Cu}$ in an acid electrolyte, which are really evident from TEM examination. This provides further insight on the mechanism of flaw generation in anodic films on Al-Cu. Although, RBS data apparently contrast with an hypothesis of oxygen bubbles generation during film growth, since is not reflected by oxygen in excess in the film, there are reason to believe, as explained later, that oxygen gas within bubbles is release during cracking-healing events. With respect to this, recent work of our group, for anodising at higher efficiencies in phosphoric acid solutions, confirms the correlation between oxygen bubbles in anodic films on $\mathrm{Al}-\mathrm{Cu}$ alloy and oxygen in excess in the film, determined by RBS.
For film growth in neutral electrolytes, the authors have previously suggested that flaw development depends on both copper cluster formation at the alloy-oxide interface and, $\mathrm{O}^{-2}$ ions that migrate inwards to the alloy-oxide interface. The formation of relatively large regions of free volume of oxide, associated originally with excess of oxygen, which is not present with high purity aluminium substrates, is clearly a consequence of the presence of copper either in the alloy or in the film. Only aluminium atoms in the alloy are oxidised in the initial stages of film growth on the $\mathrm{Al}-\mathrm{Cu}$ alloy and consequently, copper atoms accumulate in the enriched alloy layer, probably in the form of copper rich clusters ${ }^{[7]}$. The copper starts to oxidise only when sufficient copper has been accumulated in the alloy layer adjacent to the alloy-film interface. Thereafter, the average composition and thickness of the enriched layer remains approximately constant and copper and aluminium atoms are incorporated into the film in their alloy proportion ${ }^{[8]}$. For the selected electropolished condition of the Al-3.5 wt \% Cu used here, the necessary enrichment of copper in the alloy for oxidation of copper to proceed, from RBS about 33 at \%, is achieved during electropolishing treatment and is sustained by subsequent anodic film formation; 32.4 at \% (RBS).

For superpure aluminium the growth of anodic film alumina in acid electrolytes proceeds at the alloy-film interface due to the inward migration of $\mathrm{O}^{-2}$ ions. However, for the Al-Cu alloy, the alloy layer at the alloy-film interface is highly enriched in copper and $\mathrm{O}^{-2}$ ions delivered to the interface via the film may react with either aluminium or copper. With regards to the model of barrier anodic film formation on $\mathrm{Al}-\mathrm{Cu}$, as previously mentioned, copper may eventually forms clusters of fine dimensions, $1-5 \mathrm{~nm}$. The copper atoms contained in the larger clusters may react with $\mathrm{O}^{-2}$ ions moving inward, forming units of $\mathrm{CuO}$, a semiconductor oxide above which electronic transfer reaction such as oxygen evolution may proceed. The oxygen gas generated above copper cluster is mainly within bubbles in the film, which are revealed by TEM, of stripped and anodic film section, as light regions of free volume in the film ${ }^{[9]}$. Regarding the mechanism of porous film growth on aluminium, with $\mathrm{O}^{-2}$ ions moving inward for film formation at the metal-oxide interface and, the copper enrichment really revealed by TEM of anodic sections (Fig. 2) and 
RBS analysis, a similar mechanism of oxygen production is considered here. An important aspect to be considered is the location of oxygen bubbles in the oxide (Fig. 2b), which are separated and are revealed throughout the film section thickness. This indicates that the events associated with bubbles formation are possibly transient processes, mainly associated with copper cluster formation and its growth and oxidation in the metal-oxide interface. The consequence of such transient processes on the morphology of thick porous films formed on $\mathrm{Al}-\mathrm{Cu}$ alloys is actually a matter of study of our group.

\subsection{Efficiency of film growth in acid electrolytes}

An important difference between porous oxide growth on $\mathrm{Al}$ of high purity with that on the $\mathrm{Al}$ $\mathrm{Cu}$ alloy in phosphoric acid, which has been partially considered in a previous work of the authors concerning anodising of the Al-Cu alloy in sulphuric acid, is the low efficiency for film formation. During constant current anodising of the $\mathrm{Al}-\mathrm{Cu}$, the current efficiency is considerably less than that for anodising superpure aluminium under similar conditions, which is about $53.5 \%$. For anodising superpure aluminium in phosphoric acid, a loss of about $45 \%$, with respect to film growth in neutral electrolytes, is mainly due to ejection of $\mathrm{Al}^{+3}$ ions to the electrolyte ${ }^{[3]}$. Under the conditions employed here, the current efficiency of film formation, calculated from RBS and the charge passed during film formation, is as low as $21.5 \%$ in the initial stages of anodising. Thus, it is evident that there are additional sources for loss of current efficiency. As previously mentioned a main cause of the reduced efficiency for film formation on $\mathrm{Al}-\mathrm{Cu}$ may be related to oxygen evolution, which proceeds above copper cluster in the alloyfilm interface. during film growth. For film growth on $\mathrm{Al}-1.5$ at $\% \mathrm{Cu}$ at $5 \mathrm{~mA} \mathrm{~cm}^{-2}$ in neutral electrolytes to $100 \mathrm{~V}$, about $7.5 \%$ additional oxygen atoms are reported to be in the film ${ }^{[10]}$. Assuming a similar excess of oxygen in the film formed in the acid electrolyte, a charge consumed of about $0.034 \mathrm{C}$ is calculated. However, this charge represents only $3.9 \%$ of the total charge consumed during anodising the $\mathrm{Al}-\mathrm{Cu}$ to $100 \mathrm{~V}$ in phosphoric acid. Thus, besides to oxygen bubbles generation, major factors affecting current efficiency for film growth on the Al-Cu alloy are envisaged. The cause of the low efficiency for film formation may relate to cracking-healing events during film formation and consequently, to interface dissolution and re-anodising processes.

With regard to film growth on highly pure aluminium, a Pilling-Bedworth ratio of about 0.91 has been reported. Considering that a Pilling Bedworth less than 1 implies that the volume of the oxide formed is less than the volume of the metal consumed, a Pilling Bedworth even lower than 0.91 would be expected for film growth on the Al-Cu. This considering three major factors, the low efficiency for film formation, the nonuniform anodic film and the presence of bubbles in the film. From TEM examination bubbles represent $10 \%$ of the volume of the film. According to early works $^{[3]}$, the consequence of Pilling Bedworth less than 1 is that the planarity of the barrier oxide surface becomes unstable with respect to perturbation and the barrier oxide thickens under tensile stress. For the Al-Cu alloy stresses in the film are expected to be of greater importance. This, as mentioned previously, considering the presence of bubbles and the non-uniform film growth. Further, relating the morphology of the anodic film formed to $20 \mathrm{~V}$ to the voltage-time response in the initial stages of anodising, it is apparent that above impurity and second phase regions, film growth is retarded by secondary electrochemical reactions, possibly copper oxidation and oxygen evolution. Thus, an additional cause of film cracking during the initial stages of film formation is the lower rate of film formation above such regions giving rise to further development of stresses in the film. Further, cracking in the film may result in an extra loss of both, $\mathrm{Al}^{+3}$ and copper ions and, also, oxygen gas release during film formation. The last, may be the cause of the low charge consumed for oxygen evolution calculated from RBS.

From the above considerations and contrasting results between the charge consumed calculated from RBS and the real charge consumed during anodising, oxygen gas bubble generation and copper oxidation seem to be of less importance on the low efficiency for film formation. From the previous analysis, it is apparent that the main cause of loss of efficiency for film growth on the $\mathrm{Al}-\mathrm{Cu}$ is associated with generation of oxygen at residual second phase, with the development of stresses in the film and, the consequence of these effects on film cracking during film growth. 
Porous anodic film formation on and Al-3.5 wt \% Cu alloy M.A. Paez, P. Skeldon, G.E. Thompson, M. Saez, O. Bustos and A. Monsalve

\section{Acknowledgements}

The authors are grateful to DICYT (USACH) and FONDECYT (Grant: 1000797) for financial support

\section{REFERENCES}

[1] J.R. DAVIS, Aluminium and Aluminium Alloys, Editor, ASM International, 1994.

[2] G.E., Thompson, K. Shimizu and G.C. Wood, Nature $2861(980) 471$.

[3] K. Shimizu, K. Kobayashi, G.E. Thompson and G.C. Wood, Phil. Mag. A. 66 (1992) 643.

[4] X. Zhou, H. Habazaki, K. Shimizu, P. Skeldon, G.E. THOMPSON and G.C. WoOD, Corr. Sci. 38 (1996) 1563.
[5] M.A. Paez, O. Bustos, G.E. Thompson, P. Skeldon, K. SHIMIZU and G.C. WoOD, J. Electrochem. Soc. 147 (2000) 1015.

[6] X. Zhou, G.E. Thompson, H. Habazaki, M.A. PÁez, K. SHIMIzU, P. SKeldon and G.C. WoOd, J. Electrochem. Soc. 147 (2000) 1747.

[7] M.A. Paez, T.M. Foong, C.T. Ni, G.E. Thompson, K. Shimizu, H. Habazaki, P. Skeldon and G.C. WoOd, Corr. Sci. 38 (1996) 59.

[8] X. Zhou, G.E. Thompson, H. Habazaki, K. Shimizu, P. SKELDON and G.C. WoOD, Thin. Solid Films 293 (1997) 327.

[9] P. Skeldon, G.E. Thompson, G.C. Wood, X. Zhou, H. HabazAKI and K. Shimizu, Phil Mag. A. 76 (1997) 729.

[10] M.A. Páez, X.Zhou, M. Saez, P. Skeldon, G.E. THOMPSON and J.H. ZAGAL, J. ATB Metallurgie 40 (2001) 181. 